\title{
Assessment of Cytotoxic and Genotoxic Effect of Fissure Sealants in Buccal Epithelial Cells
}

\section{Procjena citotoksičnosti i genotoksičnosti materijala za pečaćenje fisura na epitelnim stanicama bukalne sluznice}

\author{
${ }^{1}$ Study of Dental Medicine, School of Medicine, University of Split, Split, Croatia \\ Studij dentalne medicine pri Medicinskom fakultetu Sveučilišta u Splitu, Hrvatska \\ 2 Department of Paediatric Dentistry, School of Dental Medicine, University of Zagreb, Zagreb, Croatia \\ Zavod za dječju i preventivnu stomatologiju Stomatološkog fakulteta Sveučilišta u Zagrebu, Hrvatska \\ ${ }^{3} 6^{\text {th }}$ year student, Study of Dental Medicine, School of Medicine, University of Split, Split, Croatia \\ student Studija dentalne medicine pri Medicinskom fakultetu Sveučilišta u Splitu, Hrvatska \\ ${ }^{4}$ Institute for Medical Research and Occupational Health, Zagreb, Croatia \\ Institut za medicinska istraživanja i medicinu rada, Zagreb, Hrvatska
}

\begin{abstract}
Aim: The main purpose of this study was to assess the genotoxic and cytotoxic effect of fissure sealants on buccal epithelial cells. Material and methods: The study was conducted on 45 patients ( 27 girls and 18 boys), seven to 16 years of age (age mean $12.09 \pm 2.20$ ). Buccal swabs were collected before (T0), seven (T1), 30 (T2) and 90 days (T3) consequently after fissure sealant placement (Helioseal $F \AA$, Equia Fil $($, Constic () . Patients or legal guardians filled in the questionnaire regarding the demographic data (age, gender), dietary habits, health status, medication usage, and recent X-ray exposure. DNA damage was analyzed using the micronucleus test. Results: Statistically significant difference in the number of buccal cells with condensed chromatin was found between T0 (time before fissure sealant placement) and T3 (90 days after fissure sealant placement) period for Helioseal $F \circledast(P=0.025)$. For the other two analyzed materials, no difference was observed during the tested period. There was no difference between materials in the same sampling time. Conclusion: Apart from an increase in cells with condensed chromatin 90 days after the placement of Helioseal $F \circledast$, no other nuclear abnormalities were observed for tested fissure sealants. Although these sealants have now largely been used, it is of high importance that their biocompatibility is checked continuously, especially in in vivo clinical studies.
\end{abstract}

Received: October 6, 2020

Accepted: February 12, 2021

Address for correspondence

Antonija Tadin

University of Split

School of Medicine

Study of Dental Medicine

Soltanska 2, 21000 Split, Croatia

Phone: +385959105094

Fax: +38521557624

atadin@mefst.hr

MeSH terms: Pit and Fissure Sealants; Materials Testing; Mutagenicity Tests; Cytotoxins; Epithelial Cells

Author keywords: Biocompatibility; Buccal epithelial cells; Fissure sealants; Micronucleus assay

\section{Introduction}

The primary assignment of dental medicine is to prevent oral disease and maintain oral health (1). Regardless of the current progress of dental medicine and the improvement of living conditions, oral diseases especially caries still cause severe problems and dysfunction of the masticatory system, which impacts the entire human body and the quality of life (2). Dental caries is a chronic disease which occurs as the interaction of host, pathogen, environment and time (3).

The morphology of the tooth, the composition and quantity of saliva, frequent meals, inadequate nutrition, and poor oral hygiene promote the formation of a carious lesion (3). About $80-90 \%$ of all caries lesions are localized occlusally, in the fissure system $(4,5)$. Food residues can remain in low and narrow fissures, saliva and microorganisms, which creates a biofilm - a complex structure that is both their nutrient substrate as well as protection from external influences (5). Ac-
Uvod

Osnovna zadaća dentalne medicine jest prevencija bolesti usne šupljine i očuvanje oralnoga zdravlja (1). Bez obzira na napredak dentalne medicine i poboljšanje životnih uvjeta, bolesti usne šupljine, posebice karijes, i dalje uzrokuju ozbiljne probleme i disfunkciju stomatognatoga sustava, što utječe na cijeli organizam i kvalitetu života (2). Zubni karijes kronična je bolest, a nastaje kao posljedica interakcije domaćina, patogena, okoliša i vremena (3).

Morfologija zuba, sastav sline, učestali obroci, neodgovarajuća prehrana te loša oralna higijena potiču nastanak karijesne lezije (3). Od 80 do $90 \%$ svih karijesnih lezija lokalizirano je okluzalno, u fisurnom sustavu $(4,5)$. Naime, u dubokim i uskim brazdama žvačnih ploha zaostaju ostatci hrane, slina i mikroorganizmi koji stvaraju biofilm - kompleksnu strukturu koja im je hranjivi supstrat, ali i zaštita od vanjskih utjecaja (5). Kiseline, kao nusprodukt metabolizma 
ids, as a by-product of carbohydrate metabolism, dissolve the inorganic components of hard tooth tissues, allowing bacteria and their toxins to penetrate deeply through the tooth structure, ultimately infecting the pulp itself, resulting in a pulp and periapical diseases (6).

Fissure sealing is an interceptive procedure in which deep and narrow fissure system is sealed with a material that can adhere to the enamel. In this way, the penetration of food and bacteria into the fissure system is prevented $(7,8)$. Sealing materials are classified into three groups: materials based on the resin, glass ionomer cement and compomers (9).

Biocompatibility is the ability of a material to function in a specific role in the presence of an adequate host response. This definition implies an interaction between the host, the materi$\mathrm{al}$, and the function that that material is supposed to perform. All three factors must be in harmony before the material can be considered biocompatible. Biocompatibility reflects the physical, mechanical and chemical properties of the material, while the adequate host response implies the ability of the tissue to withstand the presence of foreign material (10). Daily, in dental practice, many materials are used, and it is of great importance that those are not harmful or contain substances that would cause local or systemic side effects $(11,12)$.

The biocompatibility of all dental materials is essential. Primarily, they come into very close contact with human oral tissues over a long period, and the patient is unable to remove them. Since certain dental materials have already been on the market, many clinicians believe they are safe and should not be reviewed (13). But biocompatibility is not in the static state and thus is subject to change since the material is exposed to mechanical, chemical and thermal changes. Furthermore, adverse reactions often appear only after chronic exposure, and scientific studies, especially those on new materials, do not usually last long enough to obtain such data (13).

As one of many tests to assess genotoxicity, the micronucleus assay is used to evaluate the damage of genetic material during mitosis due to exposure to potential genotoxic substances $(14,15)$. The presence of micronuclei, small extranuclear structures containing fragments of damaged chromosomes in the cell, confirms the existence of damaged genetic content, which proves the genotoxic and cytotoxic effect of the tested material on the cells (16). Also, cells with damaged genetic material can pass into cells with condensed chromatin, fragmented nucleus (karyorrhexis), and pyknosis or completely lose nuclear content (karyolysis). In some cases, some cells remain in the binuclear phase (two nuclei of equal size) or have nuclear buds (17).

Thus, the aim of this in vivo study was to assess the influence of three sealing materials on the epithelial cells of the buccal mucosa. The null hypothesis was that all tested materials would not cause any genotoxic and cytotoxic effect in buccal epithelial cells.

\section{Material and methods}

The study included 45 subjects, 27 girls and 18 boys; aged seven to 16 (mean age $12.09 \pm 2.20$ ) and was conducted in Departments of Pediatric and Preventive Dentistry of ugljikohidrata iz biofilma, otapaju anorganske sastojke tvrdih zubnih tkiva te tako omogućuju bakterijama i njihovim toksinima dublji prodor kroz zubnu strukturu, a naposljetku zahvaćaju i pulpu rezultirajući širokim spektrom bolesti pulpe i periapeksa (6).

Pečaćenje fisura jedan je od interceptivnih postupaka kojim se fisurni sustav žvačne plohe zaštićuje materijalnom koji adherira na caklinu. Na taj se način sprječava prodor hrane i bakterija $(7,8)$. Materijali za pečaćenje dijele se u tri skupine - na materijale temeljene na smoli, na staklenoionomernim materijalima te na kompomerima (9).

Biokompatibilnost je svojstvo nekog materijala da funkcionira u svojoj specifičnoj ulozi uz adekvatan odgovor domaćina. Ta definicija tako podrazumijeva interakciju između domaćina, materijala i specifične funkcije koju taj materijal treba obnašati. Kako bi se materijal smatrao biokompatibilnim sva tri navedena čimbenika trebaju biti u ravnoteži. Biokompatibilnost je odraz fizikalnih, mehaničkih i kemijskih svojstava materijala, a adekvatan odgovor domaćina podrazumijeva svojstvo tkiva da podnese prisutnost stranog materijala (10). U dentalnoj medicini svakodnevno se koristi mnoštvo materijala te je presudno važno da nisu štetni, odnosno da ne sadržavaju tvari koje bi izazvale lokalne ili sistemske nuspojave $(11,12)$. Naime, dentalni materijali dolaze u dugotrajni bliski kontakt $s$ oralnim tkivom čovjeka te ih pacijent ne može sam ukloniti. Kada je neki dentalni materijal već na tržištu, mnogobrojni kliničari smatraju kako je i potpuno siguran te da njegovu biokompatibilnost ne treba dalje preispitivati (13). No, biokompatibilnost nije statično stanje, nego je podložna promjenama zbog izloženosti materijala mehaničkim, kemijskim i termičkim podražajima. Nadalje, neželjene reakcije tkiva često se pojave tek nakon kronične izloženosti, a istraživanja na novim materijalima ne traju dovoljno dugo da bi se takvi podatci odmah dobili (13).

Mikronukleusni test koristi se kao jedan od testova za procjenu oštećenja genskog materijala tijekom mitoze kao posljedica izloženosti potencijalno genotoksičnim sastojcima $(14,15)$. Prisutnost mikronukleusa, malih izvanjezgrenih staničnih struktura koje sadržavaju fragmente oštećenih kromosoma, potvrđuje postojanje oštećenoga genskog sadržaja, što dokazuje genotoksičan i citotoksičan učinak testiranog materijala na stanice (16). Stanice $s$ oštećenim genskim materijalom također mogu prijeći u stanice $s$ kondenziranim kromatinom, fragmentiranom jezgrom (karioreksa), piknozom jezgre ili potpuno izgubiti jezgreni sadržaj (karioliza). U rijetkim slučajevima neke stanice ostanu u binuklearnoj fazi (dvije jezgre podjednake veličine) ili imaju jezgrene pupove (17).

Cilj ove studije in vivo bio je ispitati utjecaj triju materijala za pečaćenje na epitelne stanice bukalne sluznice. Hipoteza je bila da nijedan od testiranih materijala nema genotoksičan i citotoksičan učinak na epitelne stanice bukalne sluznice.

\section{Materijal i metode}

U ovu studiju bilo je uključeno 45 ispitanika - 27 djevojčica i 18 dječaka u dobi od sedam do 16 godina (srednja dob $12,09 \pm 2,20)$ koji su pristupili pregledu i pečaćenju zuba u 
the School of Dental Medicine in Zagreb and Study of Dental Medicine, School of Medicine in Split, Croatia. It was approved by the Ethics Committee of the School of Dental Medicine, University of Zagreb. All patients participated voluntarily. The parents and caregivers were informed in details of the study's purpose and design and signed a consent form. Inclusion criteria were healthy children with indications for the sealing procedure on lower molars (7), with no other restorations in the oral cavity. Exclusion criteria were special health care children, children with contraindication for fissure sealing, and children with restorations. During the research, only one lower molar was sealed. The subjects were randomly divided into three equal groups, depending on the material used. The material properties and their composition as specified by the manufacturer are listed in Table 1 . The respondents, with the help of parents/caregivers, filled a questionnaire, designed for this study, in which they answered the questions related to demographic factors (age, gender), lifestyle habits (diet) and personal factors (health status, use of medications, exposure $\mathrm{X}$-ray radiation).
Zavodu za dječju stomatologiju Stomatološkoga fakulteta u Zagrebu te na Odjelu za dječju dentalnu medicinu Stomatološke poliklinike Split. Istraživanje je odobrilo Etičko povjerenstvo Stomatološkoga fakulteta Sveučilišta u Zagrebu. Svi roditelji ili skrbnici djece koja su sudjelovala u istraživanju bili su detaljno obaviješteni o svrsi istraživanja nakon čega su potpisali pristanak. Kriterij za sudjelovanje bila su zdrava djeca s indikacijama za pečaćenje fisura na donjim kutnjacima (7), bez drugih ispuna u usnoj šupljini. Kriteriji za nesudjelovanje bila su djeca s posebnim potrebama, djeca s kontraindikacijama za pečaćenje fisura i djeca s restauracijama. Tijekom ispitivanja pečatila se fisura samo na jednom donjem kutnjaku. Ispitanici su nasumično podijeljeni u tri brojčano jednake skupine, ovisno o materijalu koji se upotrebljavao za pečaćenje. Svojstva korištenih materijala i njihov sastav koji je naveo proizvođač prikazani su u tablici 1. Ispitanici su, uz pomoć roditelja/skrbnika, ispunili i upitnik predviđen za ovo istraživanje u kojemu su odgovorili na pitanja vezana za demografske čimbenike (dob, spol), životne navike (prehrana) te osobne čimbenike (zdravstveni status, korištenje lijeko-

\begin{tabular}{|c|c|c|c|}
\hline $\begin{array}{l}\text { Material • } \\
\text { Materijal }\end{array}$ & Type $\bullet$ Vrsta materijala & $\begin{array}{l}\text { Manufacture } \\
\text { Proizvođač }\end{array}$ & Chemical composition • Sastav (\%) \\
\hline Helioseal $F^{\otimes}$ & $\begin{array}{l}\text { Fluoride releasing resin-based } \bullet \text { Materijal } \\
\text { proizveden na temelju smole } s \text { dodatkom } \\
\text { fluora }\end{array}$ & $\begin{array}{l}\text { Ivoclar Vivadent, } \\
\text { Schaan, Liechtenstein • } \\
\text { Lihtenštajn }\end{array}$ & $\begin{array}{l}\text { Bis-GMA (11.8\%), TEGDMA (23.4\%), UDMA }(23.4 \%) \\
\text { silicon dioxide and fluorosilicate glass }(40.5 \mathrm{wt} \%) \text {, titanium } \\
\text { dioxide, stabilizers and catalysts }(<1 \mathrm{wt} \%) \bullet \text { fluoroslikatno } \\
\text { staklo }(40,5 \%) \text {, silicijev dioksid, titanijev dioksid, } \\
\text { stabilizatori, katalizatori }(<1 \%)\end{array}$ \\
\hline Equia Fil ${ }^{\circledast}$ & $\begin{array}{l}\text { Glass ionomer cement } \bullet \text { Staklenoionomerni } \\
\text { cement }\end{array}$ & $\begin{array}{l}\text { GC, Tokyo, Japan } \bullet \\
\text { Tokio, Japan }\end{array}$ & $\begin{array}{l}\text { Powder: strontium fluoro alumino-silicate glass }(95 \%) \text {, } \\
\text { polyacrylic acid }(5 \%) \bullet \text { Prašak: stroncij fluoroaluminosilikatno } \\
\text { staklo }(95 \%) \text {, poliakrilna kiselina }(5 \%) \\
\text { Liquid: } 40 \% \text { aqueous polyacrylic acid } \bullet \text { Tekućina: } 40 \% \\
\text { vodena otopina poliakrilne kiseline }\end{array}$ \\
\hline Constic $^{\oplus}$ & $\begin{array}{l}\text { Self-adhesive flowable composite } \bullet \\
\text { Materijal proizveden na temelju smole }\end{array}$ & $\begin{array}{l}\text { DMG, Hamburg, } \\
\text { Germany } \bullet \text { Njemačka }\end{array}$ & $\begin{array}{l}\text { Bis-GMA (15-35\%), EBADMA, UDMA, HEMA, } \\
\text { TEGDMA, HDMA (<45\%), MDP, stabilizers and catalysts • } \\
\text { stabilizatori i katalizatori }\end{array}$ \\
\hline
\end{tabular}

Abbreviations $\bullet$ Kratice: Bis-GMA - Bis-phenol A diglycidylmethacrylate • Bisfenol-A-glicidil dimetakrilat; TEGDMA - triethylene glycol dimethacrylate $\bullet$ trietilen-glikol-dimetakrilat; UDMA - urethane dimethacrylate $\bullet$ uretan-dimetakrilat; EBADMA - ethoxylated bisphenol-A dimethacrylate $\bullet$ etoksilirani bisfenol-A dimetakrilat; HEMA - 2-hydroxy ethyl methacrylate • 2-hidroksi etil-metakrilat; HDMA - 1,6-Hexanediol dimethacrylate $\bullet$ 1,6-heksandiol-dimetakrilat; MDP - 10 Methacryloyloxydecyl dihydrogen phosphate 10 metakriloiloksidecil-dihidrogen-fosfat.

The sample size was calculated by the G Power software. With a $95 \%$ confidence interval, an $80 \%$ power, and an effect size of $80 \%$ (18), a sample size of 45 (15 in each group) was necessary.

Samples of epithelial cells of the buccal mucosa were collected by the brushing technique of each subject immediately before (control, T0), seven (T1), 30 (T2) and 90 (T3) days after the fissure sealing. Participants were asked to abstain from food 1 hour before sampling, and since they are children, it implies that they did not consume alcohol or cigarettes. After the participants rinsed the oral cavity with the tap water, the swab was taken by gently brushing the buccal mucosa areas near the set material. Then, the cells collected with the brush were applied to the encrypted slides pre-heated to $37^{\circ} \mathrm{C}$. After the application, the cell samples were airdried and then fixed with methanol $(80 \% \mathrm{v} / \mathrm{v})$ at four ${ }^{\circ} \mathrm{C}$ for 20 minutes. The samples were stained with $5 \%$ Giemsa va, izloženost rendgenskom zračenju). S pomoću softvera $G$ Power izračunata je minimalna veličina uzorka potrebnog za istraživanje. Uz razinu pouzdanosti od $95 \%$, snagu testa od $80 \%$ i veličinu učinka od $80 \%$ (18), veličina uzorka potrebnog za istraživanje iznosila je 45 ispitanika (15 po skupini).

Uzorci epitelnih stanica obrazne sluznice uzeti su od svakog ispitanika tehnikom četkanja neposredno prije postupka (kontrola, T0) te poslije sedam (T1), 30 (T2) i 90 (T3) dana poslije pečaćenja fisura. Sudionici istraživanja zamoljeni su da se jedan sat prije uzorkovanja suzdrže od jela, a sama činjenica da je riječ o djeci implicira da nisu konzumirali ni alkohol, ni cigarete. Nakon što su sudionici isprali usnu šupljinu vodom iz slavine, citološkom četkicom, nježnim četkanjem područja obrazne sluznice uz postavljeni materijal, uzet im je bris sluznice. Četkicom skupljene stanice nanesene su na šifrirano predmetno stakalce zagrijano na $37^{\circ} \mathrm{C}$. Nakon nanošenja uzorci stanica na predmetnim stakalcima ostavljeni su 
solution for 10 minutes, washed with distilled water and airdried. The analysis was performed with an Olympus CX 40 light microscope (Olympus, Tokyo, Japan) at 400x magnification, while some observed chromatin anomalies were additionally tested under magnification 1000x. Two replicate slides were prepared for each sample. On each slide $2000 \mathrm{ep}-$ ithelial cells were analyzed. The occurrence of chromatin abnormalities (micronuclei, binucleated cells, condensed chromatin karyorrhexis, karyolysis, pyknosis, nuclear buds and "broken egg") was evaluated and qualified, according to Tolbert et al. (17).

\section{Statistical analysis}

For the statistical analysis of the data, the software package SPSS (IBM Corp., Armonk, New York, USA) was employed. Descriptive statistical analysis was used to determine the basic statistical parameters (mean, standard error, standard deviation, relative standard deviation, median and minimum and maximum values). The difference among the tested groups was assessed by the analysis of variance and the Tukey HSD post hoc test.

Multiple linear regression analysis was used to determine the mentioned chromatin abnormalities as the outcome variable with predictor variables. Predictor variables were: age, gender, use of medication, X-ray exposure, dietary habits such as consumption of sweets, meat, vegetables, fruits, soda drinks and tea, the time elapsed since the placement of sealing material, and also type of material (Constic ${ }^{\circ}$ was set as the base material for regression analysis). The results were expressed in Pareto diagrams. The level of significance was set at 0.05 for all tests.

\section{Results}

Figures 1 and 2 show the basic statistical parameters used to obtain results using a micronucleus test on buccal mucosal cells in three groups of subjects at four times: T0 - immediately before fissure sealing, T1 - seven days, T2 - 30 days and T3 - 90 days after sealing the fissure. A statistically significant difference in the number of cells with condensed chromatin was observed between $\mathrm{T} 0$ and $\mathrm{T} 33$ time for Helioseal $\mathrm{F}^{\circ}$ $(P=0.025)$. For other two sealant materials, there was no significant difference. No statistically significant difference was observed between the different materials, comparing the nuclear abnormalities at the same sampling time.

The dependence of the micronucleus test parameters on all predictor variables was determined by multiple regression analysis and presented in the form of a Pareto diagram (Figures 3 and 4). The appearance of cells with condensed chromatin confirmed a statistically significant effect of the following variables: $X$-ray exposure $(\beta=-0.386 ; P=0.031)$, the medication intake $(\beta=-1.041 ; \mathrm{P}=0.031)$, meat consumption $(\beta=0.332 ; \mathrm{P}=0.031)$, soft drinks consumption $(\beta=0.673 ; \mathrm{P}$ $<0.001)$, tea consumption $(\beta=-0.693 ; \mathrm{P}=0.001)$ and consumption of sweets $(\beta=-0.336 ; \mathrm{P}<0.001)$. The number of cells with condensed chromatin and karyolysis was statistically significantly affected by the type of material used for fissure da se osuše na zraku, a zatim su 20 minuta fiksirani metanolom $(80 \% \mathrm{v} / \mathrm{v})$ na temperaturi od $4{ }^{\circ} \mathrm{C}$. Uzorci su bojeni prema Gimseu 5-postotnom otopinom 10 minuta, zatim isprani destiliranom vodom te sušeni na zraku. Analiza je obavljena svjetlosnim mikroskopom Olympus CX 40 (Olympus, Tokio, Japan) pod povećanjem od 400 puta, a pojedine uočene kromatinske anomalije dodatno su provjerene pod povećanjem od 1000 puta. Svaki uzorak pripremljen je u duplikatu te je postavljen na svakom predmetnom stakalcu, a analizirano je 2000 epitelnih stanica. Pojava kromatinskih abnormalnosti (mikronukleus, binukleuklearna stanica, karioreksa, karioliza, piknoza, jezgreni pup i prepolovljeno jaje) procijenjena je i kvalificirana prema Tolbertu i suradnicima (17).

\section{Statistička analiza}

Za statističku obradu podataka korišten je programski paket SPSS (IBM Corp., Armonk, New York, SAD). Deskriptivna statistička analiza upotrijebljena je kako bi se odredili osnovni statistički parametri (srednje vrijednosti, standardne pogreške, standardne devijacije, relativne standardne devijacije, medijani te minimalne i maksimalne vrijednosti). Analizom varijance i Tukeyjevim HSD post hoc testom ispitivane su eventualne značajne statističke razlike između testiranih skupina. Višestruka regresijska analiza korištena je za procjenu povezanosti nezavisnih varijabli na zavisne varijable. Nezavisne varijable bile su dob, spol, upotreba lijekova, izloženost rendgenskom zračenju, prehrambene navike poput konzumacije slastica, mesa, povrća, voća, gaziranih pića te čaja, vremena proteklog od postavljanja ispuna te vrste upotrijebljenog materijala (Constic ${ }^{\oplus}$ je postavljen kao početni materijal za regresijsku analizu). Rezultati su prikazani u formi dijagrama Pareto. U svim testovima korištena je razina statističke značajnosti od 0,05 .

\section{Rezultati}

Na slikama 1. i 2. osnovni su statistički parametri korišteni za dobivanje rezultata s pomoću mikronukleusnog testa na stanicama bukalne sluznice u trima skupinama ispitanika $\mathrm{u}$ četirima vremenima: T0 - neposredno prije pečaćenja fisura, T1 - sedam dana, T2 - 30 dana i T3 - 90 dana poslije pečaćenja fisura. Uočena je statistički značajna razlika u broju stanica s kondenziranim kromatinom između vremena T0 i T3 za Helioseal $\mathrm{F}^{\oplus}(\mathrm{P}=0,025)$. Za ostala dva korištena materijala nije uočena statistički značajna razlika. Uspoređujući stanične promjene $\mathrm{u}$ istom vremenu uzorkovanja nije uočena nikakva statistički značajna razlika među različitim materijalima.

Ovisnost parametara mikronukleusnog testa o prediktorskim varijablama utvrđena je višestrukom regresijskom analizom i prikazana u obliku dijagrama Pareto (slike 3. i 4.).

Nakon pojave stanica s kondenziranim kromatinom potvrđeno je da statistički značajan učinak imaju sljedeće varijable: izloženost rendgenskom zračenju $(\beta=-0,386 ; \mathrm{P}=$ $0,031)$, uzimanje lijekova $(\beta=-1,041 ; P=0,031)$, konzumacija mesa $(\beta=0,332 ; \mathrm{P}=0,031)$, konzumacija gaziranih napitaka $(\beta=0,673 ; \mathrm{P}<0,001)$, čaja $(\beta=-0,693 ; \mathrm{P}=0,001) \mathrm{i}$ slastica $(\beta=-0,336 ; \mathrm{P}<0,001)$. Na incidenciju broja stanica $s$ kondenziranim kromatinom i kariolizom statistički značajno je utjecao izbor materijala. Djeca kod koje je za pečaćenje 

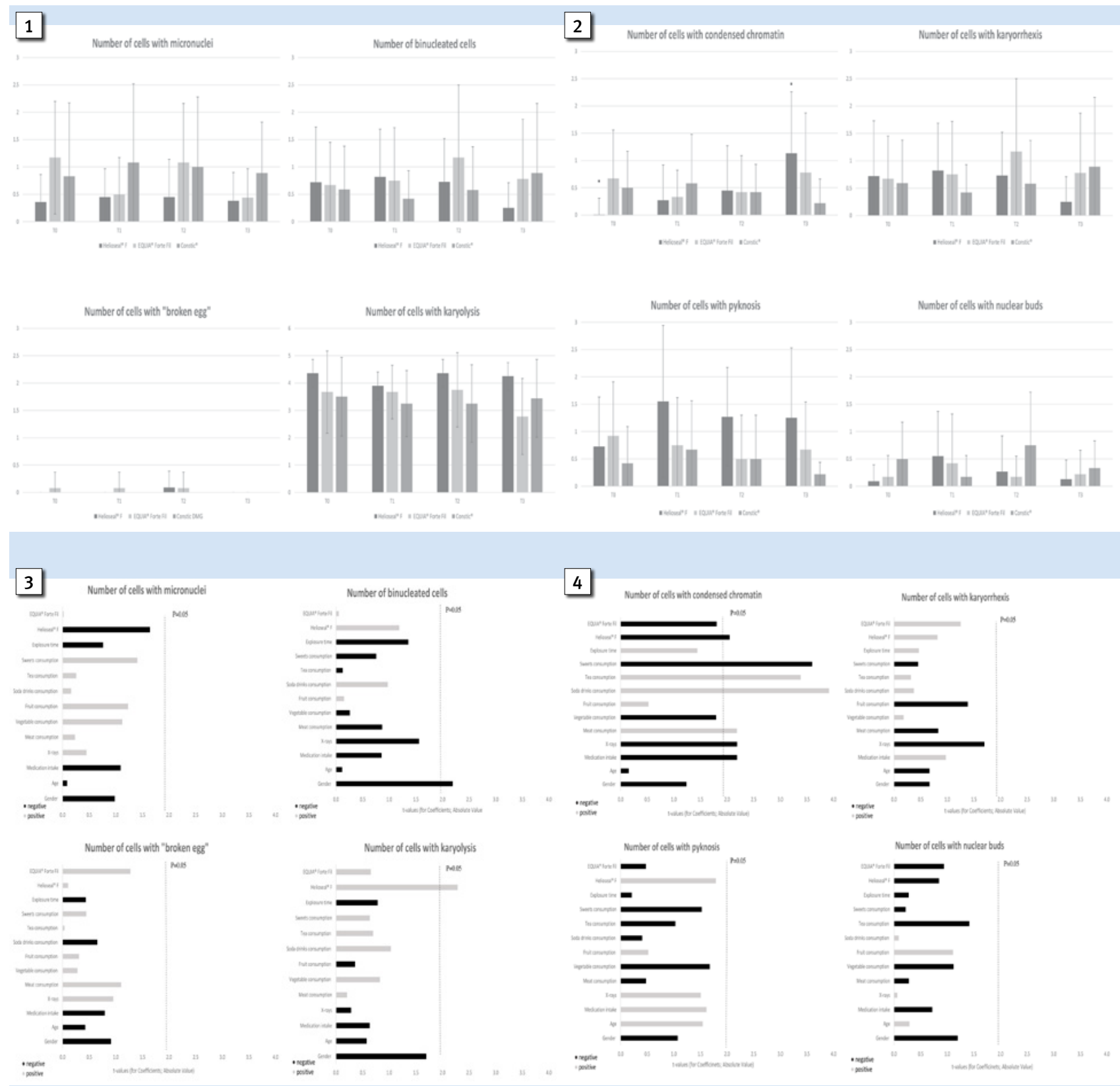

Figure 1 The frequency of cells with micronuclei, binucleated cells, cells with "broken egg " and karyolysis in 2000 buccal epithelial cells after fissure sealant placement ( $n=15 /$ material for each time-point of measurement). Mean values are expressed as columns, error bars represent standard deviations.

Slika 1. Pojavnost stanica s mikronukleusom, binuklearnih stanica, stanica s prepolovljenim jajetom i kariolizom na 2000 epitelnih stanica bukalne sluznice nakon postavljanja materijala za pečaćenje ( $N=15$ ispitanika po materijalu za svako vrijeme uzorkovanja). Srednje vrijednosti izražene su kao stupci, a crte pogreške predstavljaju standardne devijacije

Figure 2 The frequency of cells with condensed chromatin, karyorrhexis, pykosis and nuclear buds in 2000 buccal epithelial cells after fissure sealant placement ( $n=15$ /material for each time-point of measurement). Mean values are expressed as columns, error bars represent standard deviations.

Slika 2. Pojavnost stanica s kondenziranim kromatinom, karioreksom, piknozom jezgre i jezgrenim pupovima na 2000 epitelnih stanica bukalne sluznice nakon postavljanja materijala za pečaćenje ( $\mathrm{N}=15$ ispitanika po materijalu za svako vrijeme uzorkovanja). Srednje vrijednosti izražene su kao stupci, a crte pogreške predstavljaju standardne devijacije

Figure 3 Multiple regression analysis results. Association of measured cytogenetic endpoints (number of cells with micronuclei, binucleated cells, cells with "broken egg " and karyolysis) and demographic and lifestyle factors exposure duration, type of dental material and the time elapsed since the placement of sealing material.

Slika 3. Rezultati višestruke regresijske analize. Povezanost pojavnosti stanica s mikronukleusom, binuklearnih stanica, stanica s prepolovljenim jajetom i kariolizom s demografskim i životnim čimbenicima, vrstom materijala za pečaćenje i vremenom proteklim od postavljanja materijala

Figure 4 Results of multiple regression analysis. Association of measured cytogenetic endpoints (cells with condensed chromatin, karyorrhexis, pykosis and nuclear buds) and demographic and lifestyle factors exposure duration, type of dental material and the time elapsed since the placement of sealing material.

Slika 4. Rezultati višestruke regresijske analize. Povezanost pojavnosti stanica s kondenziranim kromatinom, karioreksom, piknozom jezgre i jezgrenim pupovima s demografskim i životnim čimbenicima, vrstom materijala za pečaćenje i vremenom proteklim od postavljanja materijala 
sealing. Children who had fissure sealed with Helioseal $\mathrm{F}^{\circ}$ had a significantly lower number of cells with condensed chromatin $(\beta=-0.375 ; P=0.043)$, and a higher number of cells with karyolysis $(\beta=0.932 ; \mathrm{P}=0.024)$ than those children who had fissure sealed with Constic ${ }^{\circ}$. The number of binucleated cells was affected by gender $(\beta=-0.200 ; \mathrm{P}=0.030)$.

\section{Discussion}

In this study, the potential genotoxic effect of the sealing material on the buccal mucosal epithelial cells was evaluated. The influence of each material on the appearance of micronuclei and other abnormalities of the nucleus (karyorrhexis, condensed chromatin, pyknosis, nuclear buds, "broken egg," binucleated cells, karyolysis) was observed at three different times: seven (T1), 30 (T2), and 90 (T3) days after placement.

Helioseal $\mathrm{F}^{\bullet}$ was the only material in the study, which caused a statistically significant increase of cells with condensed chromatin 90 days after fissure sealing (T3) relative to the baseline values (T0). The reason for this result could be potentially hidden in the phenomenon of the release of free, unbound (residual) monomer from the material, especially if it is improperly polymerized. In the study of Topaloglu-Ak et al. (19) the polymerization time and the amount of residual monomer released were compared, and the association of increased cytotoxicity with lower polymerization of the material was confirmed. In the in vitro study of Kurt et al. (20) conducted in 2018, the cytotoxicity and genotoxicity of release monomers of resin-based materials were confirmed with the series of tests. Furthermore, incompletely polymerized materials have lower physical properties, making them more susceptible to degradation in the oral cavity, which is an additional source of free monomer that has been proven to have a cytotoxic and genotoxic effect $(21,22)$.

Although the amount of released monomers is detectable and toxic in vitro, it has been concluded that it is still too small to cause long-term in vivo damage (23). The analysis of changes in the nucleus within the same period confirmed our hypothesis that there is no difference in genotoxicity between different fissure sealants.

Furthermore, Helioseal $\mathrm{F}^{\ominus}$ was the only material containing fluoride. Despite being one of the most important agents for remineralization process, fluoride has potentially genotoxic effect $(24,25)$. In addition, the other variables that potentially affect the occurrence of nuclear abnormalities such as gender, age, $\mathrm{X}$-rays exposures medicines intake, the consumption of meat, sweets, soda drinks and tea were analyzed $(23,26,27)$. Previous studies have confirmed that age is a variable that affects the genetic content $(26,28)$. Degenerative changes that occur with ageing are primarily the result of changes at the level of genetic material in the cells. Hence, it is not surprising that the number of recorded nuclear abnormalities detected by the micronucleus test is higher in the elderly population (28). In this study, the results obtained by multiple regression analysis that the age had a significant impact on the result were not recorded. That could be explained by the fact that all respondents were children and that the fisura korišten Helioseal $F^{\odot}$ imala su manji broj stanica s kondenziranim kromatinom $(\beta=-0,375 ; P=0,043)$ te veći broj stanica s kariolizom $(\beta=0,932 ; \mathrm{P}=0,024) \mathrm{u}$ odnosu prema djeci kod koje je za pečaćenje korišten Constic ${ }^{\circ}$. Na broj binuklearnih stanica utjecao je spol $(\beta=-0,200 ; \mathrm{P}=0,030)$.

\section{Rasprava}

U ovoj studiji procjenjivao se potencijalni genotoksični učinak materijala za pečaćenje na epitelne stanice bukalne sluznice. Utjecaj svakog materijala na pojavu mikronukleusa i ostalih patoloških promjena jezgre (binuklearna stanica, karioreksa, karioliza, piknoza, jezgreni pup i prepolovljeno jaje) promatran je u trima različitim vremenima: sedam (T1), 30 (T2) i 90 (T3) dana nakon postavljanja pečatnog materijala.

Helioseal $\mathrm{F}^{\oplus}$ bio je jedini materijal u studiji koji je uzrokovao statistički značajan porast broja stanica s kondenziranim kromatinom 90 dana poslije pečaćenja fisura (T3) u odnosu prema vrijednostima dobivenima prije postavljanja materijala (T0). Razlog za takav rezultat potencijalno se krije u fenomenu otpuštanja slobodnoga, nevezanoga (rezidualnog) monomera iz materijala, posebno ako je on nepropisno polimeriziran. U studiji Topaloglu-Aka i suradnika (19) uspoređeno je vrijeme polimerizacije i količina otpuštenoga rezidualnog monomera te je utvrđena povezanost povećane citotoksičnosti sa slabijom polimerizacijom materijala. Kurt i suradnici (20) dokazali su u studiji in vitro provedenoj 2018. godine nizom testova citotoksičnost i genotoksičnost monomera otpuštenih iz materijala temeljenih na smoli. Nadalje, fizikalna svojstva nepotpuno polimeriziranih materijala slabija su te je takav materijal podložniji degradaciji u usnoj šupljini, što je dodatni izvor slobodnog monomera dokazano citotoksičnoga i genotoksičnoga učinka $(21,22)$. Iako je količina otpuštenih monomera detektabilna i toksična in vitro, zaključeno je kako je ona ipak premala da bi dugoročno uzrokovala štetu u uvjetima in vivo (23). Analizom promjena jezgre unutar istoga razdoblja potvrđena je naša hipoteza da nema razlike u genotoksičnosti između različitih testiranih materijala.

Nadalje, Helioseal $\mathrm{F}^{\oplus}$ jedini je testirani materijal koji sadržava fluor. Iako je fluor jedna od najvažnijih tvari u procesu remineralizacije, ipak ima potencijalni genotoksični učinak $(24,25)$. Analizirane su i druge varijable, kao što su spol, dob, izloženost rendgenskom zračenju, konzumacija lijekova, mesa, slastica, gaziranih pića te čaja, koje mogu utjecati na nastanak jezgrenih anomalija $(23,26,27)$. U dosadašnjim studijama autori su potvrdili da je dob bitna varijabla koja utječe na genski sadržaj stanice $(26,28)$. Degenerativne promjene koje se događaju starenjem uglavnom su rezultat promjena na razini genskog materijala u stanici, pa ne čudi činjenica da je broj zabilježenih jezgrenih anomalija mjeren mikronukleusnim testom veći kod starijih osoba (28). U ovoj studiji rezultati dobiveni višestrukom regresijskom analizom nisu pokazali da je dob varijabla koja je značajno utjecala na rezultat, što možemo objasniti činjenicom da su svi ispitanici bili djeca te da je najstariji imao tek 16 godina. Spol je jedina prediktorska varijabla koja je pokazala statistički značajan porast broja binuklearnih stanica. Naime, uočen je veći 
oldest respondent was only 16 years old. Gender was the only predictor variable that showed a statistically significant increase in the number of binuclear cells. Namely, a higher number of binucleated cells was noticed in girls than in boys $(\beta=-0.200 ; P=0.030)$. Our results coincide with the results obtained in the research of Gajski et al. (29) in 2013 among healthy children in Croatia, in which larger numbers of binuclear cell changes were observed in girls.

To the best of our knowledge, there are no studies which studied exclusively the biocompatibility of materials for fissure sealing in vivo conditions. Namely, the existing studies were generally based on the analysis of the genotoxicity of other dental materials. However, the results of our study are consistent with previously conducted in vitro studies $(21-23,27)$.

This study has certain limitations; one of them is a relatively small number of respondents. Therefore, it would be necessary to conduct large-scale research over a more extended time in the future. In this way, an association between material and time with the occurrence of nucleus pathological changes could be observed. Since all dental materials are susceptible to degradation by the enzyme in the mouth, it is necessary to associate clinical durability of fissure sealants with possible genotoxic and cytotoxic changes in surrounding tissues. Also, it could be useful to include fissure sealants with a new monomer 12-methacryloyloxydodecyl pyridinium bromide (MDPB) with antibacterial activity $(30,31)$.

We could conclude that a need for more extensive knowledge about the safety of dental materials used in clinical practice is crucial. Sealing materials should be uncompromisingly harmless to the child. The usage of fissure sealing materials has primarily preventive effects, and even at the slightest indication of their toxicity, the ethics of their usage should be fundamentally re-examined.

\section{Conclusion}

Based on the results, the following can be concluded: Over a short period, none of the examined material showed a significant increase in the frequency of evaluated nuclear abnormalities. Over an extended period (90 days), Helioseal $\mathrm{F}^{\circ}$ caused a statistically significant increase in the incidence of cells with condensed chromatin.

\section{Acknowledgements}

We did not have any sources of funding directly relevant to the content of this manuscript. The authors received no financial support for this research. The authors wish to thank all participants for their invaluable contribution to this study.

\section{Conflict of interest}

The authors declare no conflict of interest.

Author's Contribution: K.G., L.G. - contributed to acquisition, analysis and interpretation of the data; drafting and providing final approval of the version to be published; D.G., D.Ž., A.B. - contributed to interpretation of the data; drafting the article and providing final approval of the version to be published; A.T. - contributed to the design and concept; acquisition, analysis and interpretation of the data; drafting and critical revision, supervision of the study and providing final approval of the version to be published. broj binuklearnih stanica kod djevojčica nego kod dječaka $(\beta=-0,200 ; P=0,030)$. Ti se rezultati poklapaju s rezultatima dobivenima u istraživanju Gajskoga i suradnika (29) provedenoga 2013. godine među zdravom djecom u Hrvatskoj kada je uočen veći broj binuklearnih staničnih promjena kod djevojčica.

Prema našim spoznajama nema sličnih studija u kojima su autori u uvjetima in vivo isključivo promatrali biokompatibilnost materijala za pečaćenje. Naime, postojeće studije temelje se općenito na istraživanju genotoksičnosti drugih dentalnih materijala. No rezultati našeg istraživanja slažu se s dosad provedenim studijama u uvjetima in vitro $(21-23,27)$.

Ova studija je u određenoj mjeri i limitirana, primjerice sudjelovao je razmjerno mali broj ispitanika. Zato bi bilo potrebno provesti istraživanje ne samo na većem broju ispitanika, nego i tijekom duljeg razdoblja. Na taj način mogla bi se uočiti sigurnija poveznica materijala i vremena kad je riječ o pojavi patoloških promjena jezgre. Budući da su svi dentalni materijali podložni degradaciji pod utjecajem enzima u usnoj šupljini, prijeko je potrebno povezati i kliničku trajnost pečata s eventualnim genotoksičnim i citotoksičnim promjenama okolnih tkiva. Uz to bilo bi korisno u istraživanje uključiti materijale za pečaćenje $s$ novim monomerom 12-metakriloiloksidodecil piridinij-bromidom (MDPB) koji djeluje i antibakterijski $(30,31)$.

Možemo zaključiti da je prijeko potrebno opširnije znanje o sigurnosti materijala kojima se svakodnevno koristimo u kliničkoj praksi. Materijali za pečaćenje trebaju biti beskompromisno neštetni za organizam djeteta. Njihova upotreba uglavnom je preventivna te bi se i na najmanju naznaku toksičnosti trebala iz temelja preispitati etičnost njihova korištenja.

\section{Zaključak}

$\mathrm{Na}$ temelju rezultata ovog istraživanja može se zaključiti sljedeće: u kraćem razdoblju nijedan ispitivani materijal nije pokazao značajan porast patoloških promjena jezgre; tijekom duljeg razdoblja (90 dana), Helioseal $\mathrm{F}^{\ominus}$ uzrokovao je statistički značajan porast broja stanica s kondenziranim kromatinom.

\section{Zahvale}

Nije postojao ni jedan financijski izvor bitan za sadržaj ovog teksta. Za ovo istraživanje autori nisu imali financijsku potporu. Istodobno zahvaljuju svim sudionicima za njihov neprocjenjiv doprinos studiji.

\section{Sukob interesa}

Autori nosu bili u sukobu interesa.

Doprinos autora: K. G. i L. G. - pridonijele su prikupljanju, analizi i interpretaciji podataka, izradi i stjecanju zaključnog odobrenja verzije za objavljivanje; D. G., D. Ž. i A. B. - pridonijeli su interpretaciji podataka, izradi teksta i stjecanju zaključnog odobrenja verzije za objavljivanje; A. T. - pridonijela je dizajnu i konceptu, prikupljanju, analizi i interpretaciji podataka, izradi i kritičkoj reviziji teksta, superviziji studije i stjecanju zaključnog odobrenja verzije za objavljivanje. 


\section{Sažetak}

Cilj: Glavni cilj studije bila je procjena genotoksičnog i citotoksičnog učinka materijala za pečaćenje na epitelne stanice bukalne sluznice. Materijal i metode: U istraživanju je sudjelovalo 45 pacijenata (27 djevojčica i 18 dječaka) u dobi između 7 i 16 godina (srednja dob 12,09 $\pm 2,20$ ). Brisevi bukalne sluznice uzeti su prije postupka (T0) te sedam (T1), 30 (T2) i 90 dana (T3) poslije postavljanja materijala za pečaćenje (Helioseal F®, Equia Fil®, Constic $®)$. Pacijenti i/ili njihovi zakoniti skrbnici ispunili su upitnik o demografskim podatcima (dob, spol), prehrambenim navikama, zdravstvenom statusu, korištenju lijekova i nedavnoj izloženosti rendgenskom zračenju. Rezultati: Zabilježena je statistički značajna razlika u broju epitelnih stanica bukalne sluznice s kondenziranim kromatinom između vremena T0 (prije postavljanja materijala za pečaćenje) i T3 (90 dana poslije postavljanja materijala za pečaćenje) za materijal Helioseal $F ®(P=0,025)$. Za druga dva analizirana materijala nije zabilježena statistički značajna razlika tijekom istraživanja. Nije zabilježena statistički značajna razlika među materijalima u istom vremenu uzorkovanja. Zaključak: Osim porasta u broju stanica s kondenziranim kromatinom 90 dana nakon postavljanja materijala Helioseal F®, za testirane materijale nije zabilježena ni jedna druga morfološka promjena jezgre. lako se navedeni materijali za pečaćenje svakodnevno primjenjuju, iznimno je važno kontinuirano provjeravati njihovu biokompatibilnost, posebno u kliničkim studijama in vivo.
Zaprimljen: 6. listopada 2020

Prihvaćen: 12 . veljače 2021.

Adresa za dopisivanje

Antonija Tadin

Sveučilište u Splitu

Medicinski fakultet

Studij dentalne medicine

Katedra za restaurativnu dentalnu

medicinu i endodonciju

Šoltanska 2, 21000 Split, Hrvatska

ORCID ID: 0000-0002-5365-9816,

telefon: +385959105094 ,

faks: +38521557624 ,

tadin@mefst.hr

MeSH pojmovi: materijali za pečaćenje fisura; ispitivanje materijala; test mutagenosti; citotoksini; epitelne stanice Autorske ključne riječi: biokompatibilnost, epitelne stanice bukalne sluznice, materijali za pečaćenje, mikronukleus test

\section{References}

1. Gambhir RS. Primary care in dentistry - an untapped potential. J Family Med Prim Care. 2015 Jan-Mar;4(1):13-8.

2. Baiju RM, Elbe P, Varghese NO, Remadevi S. Oral Health and Quality of Life: Current Concepts. J Clin Diagn Res. 2017 Jun;11(6):21-

3. Ceinos R, Bertrand MF, Cucchi C, Lupi L. Hierarchizing caries risk factors among first-year university students in Nice (France): a cross-sectional study. BMC Oral Health. 2017 Dec;17(1):159.

4. Pitts NB, Zero DT, Marsh PD, Ekstrand K, Weintraub JA, Ramos-Gomez F, et al. Dental caries. Nat Rev Dis Primers. 2017 May;3:17030.

5. Struzycka I. The oral microbiome in dental caries. Pol J Microbiol. $2014 ; 63(2): 127-35$.

6. Featherstone JD. Dental caries: a dynamic disease process. Aust Dent J. 2008 Sep;53(3):286-91.

7. Jurić H. Pediatric dental medicine. Zagreb: Naklada Slap; 2015.

8. Sreedevi A, Shamaz M. Sealants, Pit and Fissure. Tampa: Stat Pearls Publishing; 2019.

9. Naaman R, El-Housseiny AA, Alamoudi N. The Use of Pit and Fissure Sealants-A Literature Review. Dent J (Basel). 2017 Dec; 5(4):34.

10. Moharamzadeh K, Brook IM, Van Noort R. Biocompatibility of Resin-based Dental Materials. Materials (Basel). 2009;2 (2):51448.

11. Mousavinasab SM. Biocompatibility of composite resins. Dent Res J (Isfahan). 2011 Dec;8(Suppl 1):S21-9.

12. Mallineni SK, Nuvvula S, Matinlinna JP, Yiu CK, King NM. Biocompatibility of various dental materials in contemporary dentistry: a narrative insight. J Investig Clin Dent. 2013 Feb;4(1):9-19.

13. Elshahaw W. Biocompatibility. In advances in ceramics - electric and magnetic ceramics, bioceramics, ceramics and environment [Internet book]. Rijeka: InTech, 2011.

14. Makoto $\mathrm{H}$. The micronucleus test-most widely used in vivo genotoxicity test. Genes Environ. 2016 Oct;38:18-23.

15. Toy E, Yuksel S, Ozturk F, Karatas OH, Yalcin M. Evaluation of the genotoxicity and cytotoxicity in the buccal epithelial cells of patients undergoing orthodontic treatment with three light-cured bonding composites by using micronucleus testing. Korean J Orthod. 2014 May;44(3):128-35.

16. Luzhna L, Kathiria P, Kovalchuk O. Micronuclei in genotoxicity assessment: from genetics to epigenetics and beyond. Front Genet. 2013 Jul;4:131-7.

17. Tolbert PE, Shy CM, Allen JW. Micronuclei and other nuclear anomalies in buccal smears: methods development. Mutat Res.1992 Feb;271(1):69-77.
18. Gavic L, Gorseta K, Glavina D, Zeljezic D, Galic N, Tadin A. In vivo assessment of genotoxicity in buccal cells of children undergoing tooth restoration. Cent Eur J Public Health. 2019 Dec;27(4):31219.

19. Topaloglu Ak A, Alpoz RA, Bayraktar O, Ertugrul F. Monomer Release from Resin Based Dental Materials Cured With LED and Halogen Lights. Eur J Dent. 2010 Jan;4(1):34-40.

20. Kurt A, Altintas SH, Kiziltas MV, Tekkeli SE, Guler EM, Kocyigit A, Usumez A. Evaluation of residual monomer release and toxicity of self-adhesive resin cements. Dent Mater J. 2018 Jan;37(1):40-8.

21. Bakopoulou A, Papadopoulos T, Garefis P. Molecular Toxicology of Substances Released from Resin-Based Dental Restorative Materials. Int J Mol Sci. 2009 Sep;10(9):3861-99.

22. Söderholm KJ, Mariotti A. BIS-GMA-based resins in dentistry: are they safe? J Am Dent Assoc.1999 Feb;130(2):201-9.

23. Agarwal P, Vinuth DP, Haranal S, Thippanna CK, Naresh N, Moger G. Genotoxic and cytotoxic effects of X-ray on buccal epithelial cells following panoramic radiography: A pediatric study. J Cytol. 2015 Apr-Jun;32(2):102-6.

24. Horuztepe SA, Ergin E, Onen A, Gürgan S. Comparison of Resin Infiltration Technique with Conventional Preventive Applications on Occlusal Fissures: EDS and SEM Analyses. Acta stomatol Croat.2020 Dec; 54(4):382-91.

25. Li YM, Dunipace AJ, Stookey GK. Genotoxic effects of fluoride: a controversial issue. Mutat Res. 1988 Mar;195(2):127-36.

26. Cavalcante DNC, Crispim BDA, Grisolia BB, Viana LF, Maran NH, Solórzano JCJ, et al. Effects of age, sex, medication, and environmental conditions on genetic alterations in oral mucosa cells. Heliyon. 2019;5:e01840.

27. Tai WP, Nie GJ, Chen MJ, Yaz TY, Guli A, Wuxur A, et al. Hot food and beverage consumption and the risk of esophageal squamous cell carcinoma. Medicine (Baltimore). 2017 Dec;96(50):e9325.

28. Ferraz GA, de Oliveira Costa Neto A, de Moraes Marcílio Cerqueira $\mathrm{E}$, Cardoso Meireles JR. Effects of age on the frequency of micronuclei and degenerative nuclear abnormalities. Rev Bras Geriatr Gerontol. 2016 Jul;19:627-34.

29. Gajski G, Geric M. Orescanin V. Garaj-Vrhovec V. Cytogenetic status of healthy children assessed with the alkaline comet assay and the cytokinesis-block micronucleus cytome assay. Mutat Res. 2013 Nov;750(1-2):55-62.

30. Kuscu 0O, Sandalli N Caglar E, Fatos A. Micro-Tensile Bond Strength of Fissure Sealants Treated with Different Antibacterial Agents. Acta stomatol Croat. 2013 Sept; 47(3):209-16.

31. Spanovic N, Par M, Skenderovic H, Bjelovucic R, Prskalo K, Tarle Z. Real-time Temperature Monitoring During Light-Curing of Experimental Composites. Acta stomatol Croat. 2018 Jun;52(2):8796. 